\title{
Robert Musil, his Era and Predicaments - Explained for Readers in the Americas
}

\author{
http://dx.doi.org/10.11606/1982-88372545212
}

\section{Charlie Duff ${ }^{1}$}

\begin{abstract}
Review of: Musil, Robert. Ensaios de Robert Musil, 1900-1919. Seleção, Tradução, Textos críticos e Notas de Kathrin Rosenfield. São Paulo: Perspectiva, 2021.
\end{abstract}

As an American, I have often wondered what makes Robert Musil's sprawling novel The Man Without Qualities, written in the 1920s and the 1930s, so much harder for Americans to read than many novels of equal complexity written at the same time. Austrians and Germans consider Musil to be their greatest novelist, and German-speaking critics often describe his novel as forming, together with Ulysses and The Remembrance of Things Past, a holy trinity of great Modernist novels from the first half of the twentieth century. But most educated Americans, who take a knowledge of Joyce and Proust for granted, do not even know Musil's name or the name of his novel. Even less known here are Musil's marvelous essays, which should be highly esteemed as a complement to his fiction (and as an interesting alternative perspective to the views of the cultural and political criticism by authors like Walter Benjamin or Th. W. Adorno).

Kathrin Rosenfield's selection of Musil's early Essays 1900-1919, recently published by editora Perspectiva, not only makes a first set of these essays available to the Brazilian reader (a second selection Essays 1919-1942 will soon follow), but also provides a careful introduction, footnotes, commentaries and, above all, a remarkable Epilogue which synthesizes an insightful historical contextualization. Her chapter on "A

\footnotetext{
${ }^{1}$ Jubilee Baltimore, Inc., 25 East 20th Street, Baltimore, Maryland, MD 21218, United States of America. E-Mail: charlie@jubileebaltimore.org. ORCID: 0000-0003-1775-6878
}

\section{(cC) BY-NC}


DUFF, C. - Robert Musil, his Era and Predicaments

época de Musil em verbetes" offers a delightful way to come to grips with the intricacies of the cultural and political situation at the beginning of the XXth century, and puts into a nutshell quite a few valuable aspects which surprisingly cannot be found in the now classical studies by authors like Carl Schorske (Fin de Sciècle Vienna), or Allan Janik and Stephen Toulmin (Wittgenstein's Vienna).

Spanning the first forty years of the last century, Musil's essays catch Austria at the moment at which it became the place where Modernity met its first great test, and failed catastrophically. In 1900, when Musil began to write, Austria looked like a successful part of a harmonious and civilized world, envied both for the arts and for the sciences. Its capital, Vienna, was a byword for learning and culture, and Viennese pioneers like Schönberg, Kokoschka, and Freud were setting the program for the twentieth century. By 1942, when Musil died as a penniless exile in Switzerland, Austria had destroyed its empire and much of Europe by carelessly starting World War I, and an Austrian named Hitler had plunged the world into an even greater calamity.

Ever since then, civilized people have been trying to learn from the Austrian experience, largely out of fear that their nations may repeat it. Carl Schorske's Fin de Siècle Vienna is the best American example of this. Schorske, who was a teenager and a college student in the New Deal era, liked the political engagement of American intellectuals at that time and worried when American intellectuals pulled back from politics in the 1950s. He looked around for another society in which this phenomenon had occurred, preferably with unfortunate results, and found Vienna in the half-century before 1914. As he dug deeper, he found that something even bigger and worse had happened: the whole Austrian middle class, intellectuals and artists and businessmen and all, had pulled back from politics, leaving a void into which the whole society eventually toppled.

Because Schorske's is the accepted American view, and because I am an American who does not specialize in Austrian history, I have relied on Schorske for the past forty years for whatever thoughts I needed to have about his subject. But Kathrin Rosenfield has changed my thinking considerably with the marvelous forty-page set of "Verbetes/Definitions" with which she ends this book. I admire Rosenfield's earlier work about Greek tragedy enough to care what she thinks about anything. She has, moreover, a background that would fit her admirably for her task here, as an Austrian with French training, as an historian who has won prestigious prizes for literature and is a licensed 
DUFF, C. - Robert Musil, his Era and Predicaments

Freudian analyst, finally as a European who has made a successful career in Brazil. She knows Austria, and she knows other things. In this very short piece of writing, she has compressed a polymathic lifetime of experience and study to produce the best short introduction to the Austrian experience that I have yet encountered. I will leave the criticism of Musil's essays and Rosenfield's translation to specialists, but I am convinced that Rosenfield's "Verbetes/Definitions" have independent value as a work of history and should be treated as such.

Perhaps the place to start is with Schorske's notion that the Austrian middle class pulled back from politics. This presupposes that the middle class was politically engaged for a while and pulled back later. As Rosenfield points out, political engagement was never a high priority for the Austrian middle classes, and thus the notion of pulling back is inappropriate. Neither Austria nor the other nations/nationalities that constituted the Habsburg Empire ever went through a political "rise of the bourgeoisie," as England and France did in their vastly different ways. Instead, they had Enlightened Despotism, and most of them - and not only in the educated elite - liked it, because they had never been educated to take an active role in the practicalities of politics. When Karl Marx orated before Viennese workingmen in 1848, they rejected his call to determine their own destiny and told him point-blank that they expected their betters to take care of them. The fathers of those workingmen, after all, had served and died in the Austrian armies that had, finally and gloriously and with horrific casualties, defeated Napoleon in 1813 and 1814. It should not be surprising that they generally welcomed the enforced political quiet of the Metternich System as a return to normal life after decades of chaos and slaughter.

Rosenfield's historical survey proves to have learned much from Musil's finely analytical approach and his astute partial syntheses. When in 1848 the time seemed ripe for an upheaval that might lead to a profounder reform, Metternich's diplomacy had brought the benefits of peace and prosperity (together with tight control of the civil society by the police) and thus pampered the middle class in a complicated web of welfare, identification and loyalty towards the Imperial idea of the state. Despite their exclusion from government, they shared a culture of manners and the arts with the aristocracy: and the idealization of Kultur became the surrogate for real political participation in government. However efficient entrepreneurs and administrators proved in the running and organizing of daily life, the affairs of the state were left to the Obrigkeit - the higher powers. With brief touches, Rosenfield familiarizes the reader with this 
DUFF, C. - Robert Musil, his Era and Predicaments

highly complex situation, in which any personal will dissolved in a superpersonal dynamics of conformism. And she so enlightens what Musil shows in his novel The Man without Qualities/properties: his fiction analyses how the Austrian civil society had allowed to be dispossessed of its "own" or "proper" will, and thus can be regarded as a showcase of the general dangerous tendency of modern subjecthood, tempted to capitulate in the face of extreme complexity. When things become too complicated to deal with, individuals and communities resent the difficulty of processing the available data and prefer to delegate rational calculation and decision-making to other, more specialized entities. Rosenfield's selection of essays and her commentaries prepare particularly the readers in the Americas for a better understanding of The Man without Qualities: Musil's fiction projects and enlarges these intricate structures and projects them into the conditions of the modern state(s) of the twentieth and twenty-first centuries.

Rosenfield explains how Musil anticipates the (post)modern constellation, which grew "naturally" out of the failed revolutions of 1848. This upheaval energized some Austrian intellectuals and brought about the fall of Metternich, but no durable change resulted. There was no unified movement to create anything like the representative institutions of England and France. The most frequent demand was simply for a relaxation of censorship, a classic intellectuals' issue that had predictably little resonance in other parts of the society. Within a few months, the revolutionary fervor of that year was expressing itself, not in calls for political reform, but in armed movements for greater national freedom within the multi-ethnic Habsburg Empire. Most of the nationalist revolutionaries desired to remain subjects of the Emperor, and the central government managed to divide and reconquer the separatists.

It was not until 1866, when Prussia decisively defeated Austria in war and revealed the Empire's military weakness, that an imperial legislature was created. Although an imposing building was eventually built to house it, it remained weak, in part because national divisions paralyzed effective action, in part because the institution was simply too new to have developed the internal structures necessary to convert a large group of people into an effective body. As Rosenfield points out, the political and civic consciousness was similar in Prussia and the German Empire, however great the economic and military strength of the new nation unified by Bismarck: there was always the Iron Chancellor presiding over the creation and functioning of a parliamentary system that looked a great deal more impressive than it was. 
DUFF, C. - Robert Musil, his Era and Predicaments

If you had asked me a month ago whether the middle-class people of this Empire liked having weak political institutions, I would have said that they were frustrated by their inability to exert effective political control and eventually gave up. But Rosenfield points out that many of them never wanted to have political control in the first place. England and France were the great exemplars of representative government, and many persuasive Austrian intellectuals argued that England and France were not models for progressive nations. England, for them, meant what they called "Manchesterism," the grinding of workers into desperate poverty with no relief from the state. France meant political instability, with the constant threat of reawakening the Napoleonic nightmare. These writers depicted Germany and Austria as societies where employers cared for workmen, landlords cared for peasants, and the Emperor cared for all. Before we dismiss these rose-colored opinions, we should realize that Early Victorian England really was "Manchesterism," and that France really was unstable and militaristic. The reforms of the late $19^{\text {th }}$ and early $20^{\text {th }}$ centuries, which made England and France fairly decent democracies, had not yet occurred. When Austrians looked for a model state, they focused on Germany, not on England or France.

The Austrian middle class was also fundamentally different from the middle class in England or France, and unrecognizably different from any middle class today, in that the leaders of the middle class were largely creatures of the state. The central government involved itself in almost all enterprises of any size, from steel mills to railroads, from banks to research institutes. There was often state initiative; there was usually state money; and state money brought state control. Major companies were not altogether unlike government departments, and the heads of major firms succeeded by mastering the traditional pre-democratic skills of influencing government by cultivating courtiers, ministers, and functionaries. The leaders of the Austrian middle class were the last people in the world to desire large-scale political change.

If this had been all, it would have been interesting, but it would not be an important field of historical study today. As Rosenfield never lets us forget, Austria in the age of Robert Musil matters because it brought about the double catastrophe of world war and anti-Semitic genocide.

As she points out, the divorce of the middle classes from politics meant that too many intelligent people did not have enough practical things of adequate importance to do. Hence the excessive focus on Art and Culture that made Vienna shimmer so brightly 
DUFF, C. - Robert Musil, his Era and Predicaments

when seen from a distance. From this also came the obsession of upper middle-class people with acceptance by hereditary nobles. By 1900, although Austrian scientists were making new discoveries and Austrian artists were launching new movements, the daily life of too many educated people had settled into a routine of gilded boredom - from which they were only too glad to be awakened by the thrill of what looked like an easy war in 1914.

Austrian anti-Semitism arose from the lower middle classes and the working classes. In Austria, as in Germany, Jews owned a high percentage of businesses both large and small, so that workers could vilify Jews both on religious grounds and as part of the class struggle. As Schorske memorably said: "Liberalism meant Capitalism, and Capitalism meant Jew." By the standards of England and France, where voting depended on property ownership and the franchise was extended gradually, Austria enfranchised its working classes very quickly, too quickly, as it soon appeared; and working class voters, lifting up the issue of anti-Semitism, overwhelmed middle-class voters before middleclass people had had the chance to build stable political institutions or develop effective leaders. Demagogues in Vienna and elsewhere were making anti-Semitism their key issue by the mid-1890s and winning elections on it, further alienating educated people, not to mention Jews themselves, from representative institutions and driving them towards the old-fashioned security of Enlightened Despotism. As Rosenfield reminds us, Freud celebrated when the Emperor invalidated the fair and free election of anti-Semite Karl Lueger as Mayor of Vienna.

All in all, Rosenfield offers a remarkable introduction to this important subject within - considering the size and complexity of her subject -- an astonishingly small number of pages. I cannot think of a better way for anyone to get a thorough grounding in a short period of time. I hope that her work will soon be translated into English and receive the widest possible distribution.

\section{Bibliographic reference}

MusIL, Robert. Ensaios de Robert Musil, 1900-1919. Seleção, Tradução, textos críticos e notas de Kathrin Rosenfield. São Paulo: Perspectiva, 2021.

Recebido em 9 de agosto de 2021. Aceito em 11 de agosto de 2021. 